\title{
Impact of COVID-19 on Pregnancy and Childbirth: A Systematic Literature Review of Recent Evidence
}

\author{
Mir Ibrahim Sajid ${ }^{1}$, Shehar Bano Awais ${ }^{1}$, Khizar Salar ${ }^{1}$, Maryam Sherwani ${ }^{1}$, Nighat \\ Kamal $^{2}$, and Zahida Parveen ${ }^{3}$ \\ ${ }^{1}$ Aga Khan University \\ ${ }^{2}$ Dr Ziauddin Hospital \\ ${ }^{3}$ Ayub Medical College
}

May 12, 2020

\begin{abstract}
Aim: To evaluate the pathogenesis, risk factors, diagnosis and management strategies in pregnant women suspected or confirmed with COVID-19 infection. Methods: A literature review of published articles was carried out using keywords of corona virus (and its root derivatives), pregnancy, vertical transmission and childbirth in Medline, Cochrane, CINAHL, Clinicaltrials.gov and Web of Sciences. Clinical articles including case-control, case reports, case series and reviews published between 2019 and 2020, in English language were included. Editorials and Letter to Editors were not included. Two independent authors reviewed title and abstract of the articles and another set of two independent authors screened full text. A total of 22 articles were shortlisted for addition into the final manuscript Results: A total of 403 pregnancies were considered in the study with most of the patients in the third trimester of pregnancy. There was no maternal mortality reported in the literature, however $1.49 \%$ fetal mortality has been reported. Conclusion: The ideal management revolves around, rapid detection, prompt diagnosis and effective isolation.
\end{abstract}

\section{INTRODUCTION}

In December, 2019, a number of cases resembling viral pneumonia of unknown cause emerged in the city of Wuhan (Hubei, China). Deep and rapid sequencing analysis from lower respiratory tract samples revealed the presence of a novel coronavirus species that was later named severe acute respiratory syndrome coronavirus 2 (SARS-CoV-2) ${ }^{1}$. As of $7^{\text {th }}$ May 2020, there's been a total of 3,836,183 verified cases around the globe with 265,364 deaths and 1,307,608 patients recovering from the infection ${ }^{2}$.

SARS-CoV-2, severe acute respiratory syndrome coronavirus (SARS-CoV) and Middle East respiratory syndrome coronavirus (MERS-CoV), belongs to the Betacoronavirus genus. Although initial reports suggest SARS-CoV-2 to be less virulent than the two previous zoonotic coronaviruses infections SARS-CoV and MERS-CoV, it has proved to be far more efficient in terms of transmission between close contacts ${ }^{3,4}$. Over the last two decades, SARS-CoV and MERS-CoV infected $>10000$ persons worldwide. The mortality rate of SARS-CoV infection was $10 \%$, of which the mortality rate in pregnant women was $25 \%$, and the mortality rate of MERS-CoV infection till November 2019 was $34.4 \%$ of which the mortality rate in pregnant women was up to $37 \%^{5-7}$.

The recent viral Ebola epidemic and SARS pandemics showed that pregnant women suffer worse outcomes than non-pregnant individuals. This is attributed to the increased oxygen consumption and decreased functional residual capacity during pregnancy, hence COVID-19 may levy a greater risk in pregnant women as compared to the non-pregnant adult cohort. Moreover, pregnancy is an immunosuppressive state, and a weakened immune system makes women more susceptible to adverse infection outcomes. Even though 
there's no evidence yet, however there's a high suspicion that SARS-CoV-2 might be transmitted vertically from mother to fetus and cause clinically significant infection ${ }^{8-10}$.

This systematic review analyzes the recent literature in an attempt to help clinicians in making decisions on treating pregnant females who are suspected or a confirmed case of COVID-19. With the evolving situation and scarcity of literature, it's imperative to bring together authentic published literature on the pathogenesis of the infection, maternal and external risk factors, diagnosis and management of such patients.

\section{METHODOLOGY}

A literature review of published articles was carried out by two independent authors using the keywords: Corona Virus (and its derivatives to expand the search pool: COVID-19, n-CoV, novel corona virus), Pregnancy, Childbirth and Vertical Transmission. This search was carried out on Medline, Cochrane Database, Web of Sciences, Clinicaltrials.gov and CINAHL. Articles were filtered according to years (2019-2020) and articles in English language were kept. Editorials and Letter to Editors were not included in the initial search, however case reports and case series were included to increase the number of cases and variety of presentation. Various guidelines and expert perspective reports were also included to enhance the content of the manuscript as being efficient resource for readers and clinical practitioners.

Two independent reviewers initially screened the articles on the basis of title and abstract. The shortlisted articles then underwent full text review by two independent authors. Any discrepancies were resolved by a third author. Risk bias analysis and quality of non-randomized studies such as case-control and cohort studies was judged using Newcastle Ottawa Score (NOS), case reports/series using "Methodological Quality of Case Reports and Case Series" (MQC): a validated scale published in BMJ ${ }^{11}$ and systematic reviews using AMSTAR reporting guidelines ${ }^{12}$.

Data from the manuscript was then extrapolated on a pre-structured worksheet. Due to limitation of time, the review was not registered in any registry however all the corresponding authors have been kept in loop with respect to every aspect of manuscript preparation. Due to time constraints, the systematic review couldn't have been registered in PROSPERO. PRISMA guidelines for conduction of systematic review was followed to ensure accuracy and consistency ${ }^{13}$.

\section{RESULTS}

A total of 22 articles were shortlisted for addition into the final manuscript. The PRISMA flow diagram of study selection at all stages can be visualized in Figure 1. Two of the full texts were excluded due to wrong population: discussing Middle Eastern Respiratory Syndrome (MERS) and eight articles were excluded because they were either editorials or commentaries.

The accepted articles can be visualized in Table 1 below. NOS measures the risk bias and quality of the cohort and case control manuscripts on bases of three variables: selection (scored out of 4 stars, represented in the first row of table), comparability (scored out of 2 stars, represented in the second row of the table) and exposure (measured out of 3 stars, represented in the third row of the table). A score of 7 or more is expected to be a good score. MQC measures the quality of methodology using selection (scored out of one plus sign), ascertainment (scored out of 2 plus signs), causality (scored out of 4 plus signs), and reporting (scored out of 1 plus sign). A score of 6 or more was considered a good score. AMSTAR score was used in reviewing the methodology of included systematic reviews. AMSTAR marks on 11 components with yes, partial yes and no. To make the evaluation brief, these three scores are grouped together and the final score is given in the table. The guidelines were not evaluated because of the exhaustive process and time constraints. Perspective reports and technical documents were subjectively screened for risk bias assessment.

The demographics of patients in terms of trimester of pregnancy in which diagnosis is made, the geographical location of patient(s) and symptoms warranting screening and testing are included in the studies are shown in Table 2 . A total of 403 pregnancies were considered in the study with most of the patients in the third trimester of pregnancy. Due to high volumes of data from China, most of the studies either originates from mainland China or are published by Chinese authors. In the cohort sampled, there was no maternal 
mortality reported and only 6 different fetal mortalities have been reported by Schwartz et al, Zaigham et al, Panah et al and Mullins et al. of which there was 1 intrauterine, 1 still birth and the other 4 neonates expired shortly after birth ${ }^{14-17}$.

\section{Risk Factors}

\section{Maternal Risk Factors}

Pregnant women are usually considered a high-risk group for viral infections, such as SARS-CoV-2. The pregnancy induces physiological immunosuppression in women, making the mother more vulnerable to severe infections. The anatomical changes in mothers such as an increase in the transverse diameter of the thoracic cage and an elevated level of the diaphragm decreases maternal tolerance to hypoxia. The changes in lung volume and physiological vasodilation can lead to mucosal edema and increased secretions in the upper respiratory tract. In addition, alterations in cell-mediated immunity contribute to the increased susceptibility of pregnant women to be infected by intracellular respiratory pathogens like COVID-19 and cause severe pneumonia $^{14,18-20}$.

This immunosuppressive alteration in pregnancy may result due to the attenuation in cell-mediated immunity by Th1 cells due to the physiological shift to a Th2 dominant environment, which contributes to overall infectious morbidity by increasing maternal susceptibility to intracellular pathogens like viruses. However Dashraath et al postulated that changes in the hormonal levels during pregnancy which influence immunological activity against viral pathogens, in addition to physiological shift to a predominant Th2 response, may favor the expression of anti-inflammatory cytokines (IL-4 and IL-10) and other unknown immune adaptations which may serve as the predominant immune response to SARS-CoV-2, thereby resulting in a lesser severity of COVID- 19 infection as compared to the non-pregnant cohort. ${ }^{21-23}$.

Changes in the cardiovascular and respiratory systems, including increased heart rate, stroke volume, oxygen consumption, and decreased lung capacity, as well as the development of immunologic adaptations that allow a mother to tolerate an antigenically distinctive fetus, increases the risk for pregnant women to develop severe respiratory disease. It is significant that these co-morbid maternal conditions, which included preeclampsia, pregnancy-induced hypertension, uterine scarring, gestational diabetes, and uterine atony, does not appear to be significant risk factors for intrauterine transmission of SARS-CoV-2 to the fetus ${ }^{17}$.

\section{Other Risk Factors}

Among the other risk factors which can influence the infectious disease process are summarized in Table 3. These risk factors include but are not limited to environmental, occupational and healthcare associated exposure to COVID-19. Most of these patients had an environmental exposure to already SARS-VoV-2 confirmed patients, while others had been exposed to an infected person without knowing it otherwise.

\section{Pathogenesis}

\section{Mechanism of Materno-Fetal Transmission}

Possible discussion on the vertical transmission have been discussed by many authors with most of them believing there's insufficient data on vertical transmission from the mother to her fetus ${ }^{24-27}$. Scientists have run SARS-CoV-2 RT-PCR analysis on COVID-19 positive mothers' breastmilk samples and specimens of amniotic fluid, blood from the umbilical cord and throat swabs from the neonates. All of these tests have found a negative presence of the viral antigen in the abovementioned specimens, thereby making the physicians unsure of materno-fetal transmission ${ }^{16}$.

A possible vertical transmission was reported in a 34 weeks gestational mother who presented with respiratory difficulties, had patchy-ground-glass opacities on Chest CT and had a positive RT-PCR on nasopharyngeal swabs. Her infant girl was delivered by caesarian section in a negative pressure isolation room and had no symptoms, but was immediately quarantined in the neonatal intensive care unit. After 2 hours of birth, her the SARS-CoV-2 IgG level were reported to be $140.32 \mathrm{IU} / \mathrm{mL}$ and the IgM level were recorded at 45.83 $\mathrm{IU} / \mathrm{mL}$. Immunological cytokines such as IL-6 and IL-10 were raised at $28.26 \mathrm{pg} / \mathrm{mL}$ and $153.60 \mathrm{pg} / \mathrm{mL}$ 
respectively with an elevated white blood cell count of $18.08 \times 10^{\wedge}$ 9/L. Her SARS-CoV-2 IgM and IgG level remained above normal limits at the time of discharge 15 days after birth. This too was consistent with abovementioned findings of negative SARS-CoV-2 breastmilk RT-PCR ${ }^{28}$.

Among other plausible ways of SARS-CoV-2 infection, in addition to vertical transmission are: close contact transmission, droplet transmission from family members \& family visitors and nosocomial infections. If the mother does get tested positive, the newborn should be isolated and observed as soon as possible, and nucleic acid tests should be carried out, too. In addition, breastfeeding should not be performed if the mother was infected by SARS-CoV-2 ${ }^{29}$, even though WHO strictly doesn't prohibit breastfeeding, it does recommend caution.

\section{Outcomes in mothers who develop COVID-19 Pneumonia}

There is a significant understanding that the signs and symptoms of COVID-19 infection are similar in the pregnant female and their counterpart cohort. Studies have evaluated that pregnant mothers may develop postpartum fever and chest radiography similar to non-pregnant females. The common symptoms include fever, dry cough, myalgia, fatigue, dyspnea and anorexia ${ }^{1,24,26,30}$. Liu D et al evaluated if the pneumonia aggravated in mothers after giving birth to their off-springs. The authors obtained chest CTscan images before and after delivery and concluded that there was no significant difference between the two radiographs ${ }^{20}$.

However, some believe that mothers who develop SARS-CoV-2 during pregnancy are more predisposed to complications for themselves and their fetus. These include, but are not limited to rupture of membranes, preterm delivery, respiratory distress, fetal distress, coagulopathy accompanied by liver dysfunction and in severe cases, the death of the mother ${ }^{15}$. Hyperpyrexia can cause miscarriage in first and early second trimester and cause intrauterine death in late second and the third trimester. Hence fever control is very important during the infection and can be achieved by paracetamol or cold sponging or both.

Effects on Fetus 83 Neonates of COVID-19

Despite many authors not reporting adverse neonatal outcomes, Zhu et al. reported one neonatal death among six neonates who were tested positive for COVID-19 at their neonatal intensive care unit. The first symptom in all the newborns was shortness of breath, followed by fever, thrombocytopenia accompanied by abnormal liver function, tachycardia, vomiting, and pneumothorax. The authors reported that 6 out of 10 neonates admitted to their center were born prematurely and 8 out of 10 were delivered by Cesarean section, the two important predictors of adverse outcomes, as per the authors ${ }^{14,31}$.

Shwartz et al. reported extensive neonatal outcomes in children born to COVID-19 positive mothers. Authors reported cases of 10 children who were evaluated using the Pediatric Critical Illness Score (PCIS). Six of the newborns had a PCIS of less than 90 (the lesser the scores, the worse the predicted outcomes) with 6 infants developing shortness of breath, two were febrile and one of them had a significant tachycardia. Gastrointestinal symptoms such as gastric bleeding, refusal to feed, feeding intolerance and abdominal bloating was observed in 4 infants. The chest radiograph abnormalities in 7 newborns at the time of admission comprised of infection in 4, neonatal respiratory distress syndrome in 2 and pneumothorax in 1 infant. Two infants had the onset of thrombocytopenia associated with liver dysfunction. One premature infant developed shortness of breath and fluctuations of oxygenation with decreased platelets and was treated with respiratory support and transfusions accordingly. There was one neonatal fatality among the cohort, that of a premature child. Pharyngeal swab specimens were collected from 9 of the neonates between 1- and 9-days following delivery and tested for SARS-CoV-2, and all were negative ${ }^{17}$.

\section{Diagnosis}

What is a suspected case?

A person is labelled as a 'suspected case' if she meets either of the following criteria ${ }^{24}$ : 
- A patient with acute respiratory illness (fever and at least one sign/symptom of respiratory disease (e.g. cough, shortness of breath) AND with no other etiology that fully explains the clinical presentation AND a history of travel to or residence in a country/area or territory reporting local transmission of COVID-19 infection during the 14 days prior to symptom onset

- A patient with any acute respiratory illness AND who has been in contact with a confirmed or probable COVID-19 case (see definition of contact below) in the 14 days prior to onset of symptoms

- A patient with severe acute respiratory infection (fever and at least one sign/symptom of respiratory disease (e.g. cough, shortness breath) AND requiring hospitalization AND with no other etiology that fully explains the clinical presentation.

What is a probable case?

A person is labelled as a 'probable case' if she has non-specific symptoms and for whom laboratory testing for COVID-19 is inconclusive ${ }^{24}$.

What is a confirmed case?

A person is labelled as a 'confirmed case' of COVID-19 if she has a laboratory confirmation of SARS-CoV-2 infection, irrespective of clinical signs and symptoms ${ }^{24}$.

Chest Radiography in diagnosis of COVID-19 in Pregnant Women

Chest imaging including Chest X-rays and CT scan can supplement and augment the diagnosis of the viral infection but cannot replace molecular confirmation of COVID-19 by RT-PCR. The predominant findings are peripheral airspace shadowing on a plain chest radiograph. However CT scan has a higher sensitivity and efficiency than chest X-ray. The classical findings are bilateral, multi-lobar ground-glass opacities (GGO) or consolidation on CT scan of the chest. Perhaps the most specific CT scan finding is the presence of ground-glass opacification in either one field or bilaterally. These opacifications can occur as a single patchy consolidation or as multiple patchy infiltrates ${ }^{1,5}, 8,15,21,32,33$.

Liu $\mathrm{H}$ et al. however remarked that the consolidation lesions were more prevalent in the pregnant cases. They showed that even though the non-pregnant and the pregnant groups shared the same peripheral lung lesion distribution, the consolidation was significantly more frequent in the pregnant adults group. This shows that the pregnant cohort was more predisposed to pulmonary involvement in CT scan. Common CT scan presentations included: pure GGO, GGO with consolidation or reticulation, and complete consolidation with predominantly peripheral distribution and bilateral lung involvement. The abovementioned features will facilitate the diagnosis of COVID-19 pneumonia $^{32}$.

Ultrasound in diagnosis of COVID-19 in Pregnant Women

Moro et al ${ }^{34}$ devised pathological ultrasound patterns in pregnant females when compared to those expected in a normal lung, with particular emphasis on those more indicative of COVID-19 infection. The normal lung ultrasound will show A-Lines which are hyperechoic, repetitive reverberations, at regular intervals of the pleural line. The authors discuss 4 different presentations:

1. B-Lines: These occur when the lung loses normal aeration, but is not completely consolidated, it creates vertical artifacts of varying lengths and shapes, referred to as the B-Lines. These can occur in the setting of interstitial lung disease, pulmonary fibrosis etc. and have to be clinically correlated. With early stages of COVID-19, the pleural line is usually irregular, thickened, and have a characteristic distribution (multifocal, monofocal, patchy etc.) surrounded by normal lung field and no gravitational distribution.

2. White Lung: When the density of the peripheral lung parenchyma is increased as in the settings of SARS-CoV-2 acute respiratory distress syndrome (ARDS), ultrasound examination shows a white area which has no visible A or B lines.

3. Consolidation: This presentation occurs in the setting of pneumonia or atelectasis, when the lung is almost completely collapsed. In pathology such as COVID-19 pneumonia, advanced ARDS, or 
bronchiolitis, the lung may present only small subpleural, hypoechoic consolidations.

4. Pleural Effusion: In general, pleural effusion can be simple and uniformly anechoic or complicated by the presence of hyperechoic spots due to blood, pus, fibrin and/or septa.

\section{Hematological Workup in diagnosis of COVID-19 in Pregnant Women}

The most common SARS-CoV-2 hematological disturbances noted are lymphopenia, lowered counts of neutrophils, C-reactive protein (CRP) and alanine aminotransferase (ALT) with a mildly increased D-dimer count $^{1,14,15,17}$. Levels of AST and eosinophils are either similar to the control population or higher. However, some authors have reported higher ALT, AST and CRP levels in their patients, along with lymphopenia ${ }^{5,20}$. A consistent finding is a raised WBC, neutrophils, eosinophils, and CRP count in postpartum blood tests of pneumonia patients ${ }^{3,17}$.

\section{Management}

\section{Management of Patient in COVID-19 Designated Clinics}

A flowchart to designate the procedures to be followed when a patient who suspects COVID-19 comes to a designated clinic is shown in the Figure 2 [Adapted from Chen D et al ${ }^{35}$ ]. The chart focuses on getting rapid testing to confirm the diagnosis of the infection, isolation in a timely fashion, and developing multidisciplinary strategies to mitigate the risk of maternal or fetal morbidity and mortality.

\section{Management of Suspected and Confirmed Cases}

The management of suspected and confirmed cases can be evaluated in Table 4. These strategies have been formulated using the guidelines proposed by CDC and principles suggested by Rasmussen et al. ${ }^{36}$

Among other recommendations to deal with confirmed cases are:

1. Kalafat et al: The authors commenced the treatment of their patient with azithromycin, hydroxychloroquine and oseltamivir as per Turkish national COVID-19 treatment guidelines. Favipiravir and steroids were added to her treatment regimen later ${ }^{37}$.

2. Mullins et al. recommends that the decision regarding the mode of delivery should be an obstetric indication and not on presumed protection of the infant ${ }^{16}$.

3. $\mathrm{Li} \mathrm{N}$ et al. recommend the use of regional anesthesia because it is known to be safer for both mother and fetus than general anesthesia. The authors also recommended to limit the aerosols generated during the procedure. It's also recommended to ensure that the patient has donned adequate facial mask to protect her from nosocomial infection ${ }^{3}$.

4. Wang $S$ et al: Treated the mother with $40 \mu \mathrm{g}$ of recombinant human interferon $\alpha 1$ b-atomized inhalation with $2 \mathrm{~mL}$ of sterilization injection water twice daily and ganciclovir ( $0.25 \mathrm{~g}$ every 12 hours, intravenously). They also added Abipenem ( $0.3 \mathrm{~g}$ every 12 hours, intravenously) and moxifloxacin (0.4 g once daily, intravenously) to the treatment regime. The child was treated with methylprednisolone (40 mg once daily, intravenously) ${ }^{5}$.

\section{Indications for terminating pregnancy}

The guidelines on deciding termination of pregnancy have been suggested by Wang SS et al. ${ }^{29}$ and they are based on:

1. Obstetric Indications: judging according to the specific situation and indications for termination of pregnancy

2. Severe and Critically ill cases of COVID-19 pneumonia: in which cases continuing pregnancy may endanger the life of the mother and the fetus. The severe and critical states refer to:

- Severe cases refer to respiratory distress (respiratory rate [?]30 beats/min); or oxygen saturation [?]93\% at rest; or arterial blood oxygen pressure (PaO2)/oxygen concentration (FiO2) [?]300 mmHg.

- Critically ill patients refer to cases with respiratory failure and requirement for mechanical ventilation; or shock; or complications of other organ failure requiring ICU monitoring and treatment. 
The termination can then be carried out vaginally when the illness is mild, there are favorable cervical conditions, mother is already in labor and there are no contraindications present to SVD. Surgical termination is reserved for severe and critical cases as mentioned above.

\section{Precautions}

Precautionary measures for mothers and fetus

The following precautionary measures, although mentioned above, should be taken for and by the pregnant patient infected with SRS-CoV-2:

1. Wearing facial masks or appropriate N-95 respirators

2. Negative pressure isolations

3. Quarantine and maintaining social distancing

4. Practicing good hand and respiratory hygiene

5. Avoid breastfeeding the newborn until neonatologists and gynecologists deem suitable

6. Avoid the unnecessary use of corticosteroids

7. Make sure that before any CT examination, the patient's lower abdomen and pelvis is covered with a lead blanket to prevent harm to the fetus

8. Triage pregnant females to avoid unnecessary exposure in hospital settings

Precautionary measures for newborns

The following recommendations, although mentioned above, have been suggested for the care of the newborn:

1. Isolate for 14 days if mother is tested COVID-19 positive or if the child itself has been proven infected with the viral illness

2. Transfer to a neonatal intensive care unit for close monitoring of respiratory compromise

3. Avoid breastfeeding and prefer the use of formula milk

Precautionary measures for OBGYN Healthcare Providers

It is imperative that the healthcare providers themselves stay vigilant and monitor themselves daily for signs and symptoms of COVID-19. Proper PPE for contact, droplet and airborne precautions should be used as mentioned above to ensure risk of cross contamination with the patients. Where possible, extra staff should not be present in the labor room to prevent overcrowding. Institute's infectious diseases department and state health department should be notified of any patient who is suspicious or a confirmed case of COVID- $19^{21}$.

\section{Vaccinations}

No vaccinations have been proposed for the management of SARS-CoV-2 in pregnant females at the time of writing this manuscript.

\section{CONCLUSION}

Efficient obstetric treatment is the key in optimizing the prognosis of both: the mother and the child. Extensive care should be taken to determine the timing and mode of delivery, preparation of a safe-todeliver labor room and the choice of anesthesia with detailed newborn observation. Regular follow-up visits should be scheduled to monitor the health of the mother and her newborn.

\section{LIMITATIONS}

The limitations of this study include:

1. Inability to be registered with systematic review databases such as PROSPERO

2. Due to rapidly evolving data, figures quoted are those written at the time of constructing this manuscript

3. Grey literature and clinical trials couldn't be added because of scarcity of data 
4. Technical reports and perspective reports couldn't undergo risk bias assessment and hence qualitative reporting was done.

5. The guidelines were not evaluated because of the exhaustive process and time constraints

\section{CONFLICT OF INTEREST}

All the authors confirm that there is no conflict of interest associated with the production of this manuscript

FUNDING

No funding was received by any author or author's institute in development of this manuscript

\section{AUTHOR CONTRIBUTION}

All the authors contributed equally in the production of this manuscript

\section{REFERENCES}

1. Yu N, Li W, Kang Q, Xiong Z, Wang S, Lin X, et al. Clinical features and obstetric and neonatal outcomes of pregnant patients with COVID-19 in Wuhan, China: a retrospective, single-centre, descriptive study. Lancet Infect Dis. 2020;24(20):30176-.

2. COVID-19 Coronavirus Pandemic, Worldometer. Available from: https://www.worldometers.info/coronavirus [Accessed 13 April 2020].

3. Li N, Han L, Peng M, Lv Y, Ouyang Y, Liu K, et al. Maternal and neonatal outcomes of pregnant women with COVID-19 pneumonia: a case-control study. Clinical infectious diseases : an official publication of the Infectious Diseases Society of America. 2020;30(5813589).

4. Wu Z, McGoogan JM. Characteristics of and important lessons from the coronavirus disease 2019 (COVID19) outbreak in China: summary of a report of 72314 cases from the Chinese Center for Disease Control and Prevention. Jama. 2020 Feb 24.

5. Wang S, Guo L, Chen L, Liu W, Cao Y, Zhang J, et al. A case report of neonatal COVID-19 infection in China. Clinical infectious diseases : an official publication of the Infectious Diseases Society of America. 2020;12(5803274).

6. World Health Organization. Summary of probable SARS cases with onset of illness from 1 November 2002 to 31 July 2003. Available at: https://www.who.int/csr/sars/country/table2004_04_21/en/. Accessed April 2004.

7. World Health Organization. Middle East respiratory syndrome coronavirus (MERS-CoV). 2019. Available at: http://www.who.int/emergencies/merscov/en/. Accessed November 2019.

8. Fan C, Lei D, Fang C, Li C, Wang M, Liu Y, et al. Perinatal Transmission of COVID-19 Associated SARS-CoV-2: Should We Worry? Clinical infectious diseases : an official publication of the Infectious Diseases Society of America. 2020;17(5809260).

9. Lyman M, Mpofu JJ, Soud F, Oduyebo T, Ellington S, Schlough GW, Koroma AP, McFadden J, Morof D. Maternal and perinatal outcomes in pregnant women with suspected Ebola virus disease in Sierra Leone, 2014. Int J Gynaecol Obstet. 2018 Jul;142(1):71-77.

10. Lee N, Hui D, Wu A, Chan P, Cameron P, Joynt GM, et al. A major outbreak of severe acute respiratory syndrome in Hong Kong. N Engl J Med 2003; 348:1986-94.

11. Murad MH, Sultan S, Haffar S, Bazerbachi F. Methodological quality and synthesis of case series and case reports. BMJ Evid Based Med. 2018 Apr 1;23(2):60-3.

12. Sequeira-Byron P, Fedorowicz Z, Jagannath VA, Sharif MO. An AMSTAR assessment of the methodological quality of systematic reviews of oral healthcare interventions published in the Journal of Applied Oral Science (JAOS). J Appl Oral Sci. 2011 Oct;19(5):440-7. 
13. Moher D, Liberati A, Tetzlaff J, Altman DG. Preferred reporting items for systematic reviews and meta-analyses: the PRISMA statement. Ann. Intern. Med. 2009 Aug 18;151(4):264-9.

14. Zaigham M, Andersson O. Maternal and Perinatal Outcomes with COVID-19: a systematic review of 108 pregnancies. Acta obstetricia et gynecologica Scandinavica. 2020;7(10):13867-.

15. Panahi L, Amiri M, Pouy S. Risks of Novel Coronavirus Disease (COVID-19) in Pregnancy; a Narrative Review. Archives of academic emergency medicine. 2020;8(1):e34. eCollection 2020.-e34. eCollection .

16. Mullins E, Evans D, Viner RM, O'Brien P, Morris E. Coronavirus in pregnancy and delivery: rapid review. Ultrasound in obstetrics \& gynecology : the official journal of the International Society of Ultrasound in Obstetrics and Gynecology. 2020;17(10):22014-.

17. Schwartz DA. An Analysis of 38 Pregnant Women with COVID-19, Their Newborn Infants, and Maternal-Fetal Transmission of SARS-CoV-2: Maternal Coronavirus Infections and Pregnancy Outcomes. Archives of pathology \& laboratory medicine. 2020;17(10):901-2020.

18. Goodnight WH, Soper DE. Pneumonia in pregnancy. Crit Care Med. 2005;33:S390-7.

19. O'Day MP. Cardio-respiratory physiological adaptation of pregnancy. Semin Perinatol. 1997;21:268-75.

20. Liu D, Li L, Wu X, Zheng D, Wang J, Yang L, et al. Pregnancy and Perinatal Outcomes of Women With Coronavirus Disease (COVID-19) Pneumonia: A Preliminary Analysis. AJR American journal of roentgenology. 2020;18:1-6.

21. Dashraath P, Jing Lin Jeslyn W, Mei Xian Karen L, Li Min L, Sarah L, Biswas A, et al. Coronavirus Disease 2019 (COVID-19) Pandemic and Pregnancy. American journal of obstetrics and gynecology. 2020;23(20):30343-4.

22. Littauer EQ, Esser ES, Antao OQ, Vassilieva EV, Compans RW, Skountzou I. H1N1 influenza virus infection results in adverse pregnancy outcomes by disrupting tissue specific hormonal regulation. PLoS Pathog 2017;13e1006757-e1006757.

23. H, Guo JMS, Chen W, et al. Clinical characteristics and intrauterine vertical transmission potential of COVID-19 infection in nine pregnant women: a retrospective review of medical records. Lancet 2020; published online Feb 12. DOI: https://doi.org/10.1016/S0140-6736(20)30360-3.

24. Poon LC, Yang H, Kapur A, Melamed N, Dao B, Divakar H, et al. Global interim guidance on coronavirus disease 2019 (COVID-19) during pregnancy and puerperium from FIGO and allied partners: Information for healthcare professionals. International journal of gynaecology and obstetrics: the official organ of the International Federation of Gynaecology and Obstetrics. 2020;4(10):13156-.

25. Poon LC, Yang H, Lee JCS, Copel JA, Leung TY, Zhang Y, et al. ISUOG Interim Guidance on 2019 novel coronavirus infection during pregnancy and puerperium: information for healthcare professionals. Ultrasound in Obstetrics \& Gynecology.

26. Chen S, Liao E, Shao Y. Clinical analysis of pregnant women with 2019 novel coronavirus pneumonia. Journal of medical virology. 2020;28(10):25789-.

27. Chen Y, Li Z, Zhang YY, Zhao WH, Yu ZY. Maternal health care management during the outbreak of coronavirus disease 2019 (COVID-19). Journal of medical virology. 2020;26(10):25787-.

28. Dong L TJ, He S, Zhu C, Wang J, Liu C, Yang J. . Possible vertical transmission of SARS-CoV-2 from an infected mother to her newborn. . JAMA. 2020.

29. Wang SS, Zhou X, Lin XG, Liu YY, Wu JL, Sharifu LM, et al. Experience of Clinical Management for Pregnant Women and Newborns with Novel Coronavirus Pneumonia in Tongji Hospital, China. Curr Med Sci. 2020;26(10):20-2174. 
30. Chen HJ, Guo JJ, Wang C, Luo F, Yu XC, Zhang W, et al. Clinical characteristics and intrauterine vertical transmission potential of COVID-19 infection in nine pregnant women: a retrospective review of medical records. Lancet (London, England). 2020;395(10226):809-15.

31. Zhu H, Wang L, Fang C, et al. Clinical analysis of 10 neonates born to mothers with 2019-nCoV pneumonia. Transl Pediatr. 2020;9:51-60.

32. Liu H, Liu F, Li J, Zhang T, Wang D, Lan W. Clinical and CT imaging features of the COVID-19 pneumonia: Focus on pregnant women and children. The Journal of infection. 2020;20(20):30113-8.

33. Lee DH, Lee J, Kim E, Woo K, Park HY, An J. Emergency cesarean section on severe acute respiratory syndrome coronavirus 2 (SARS- CoV-2) confirmed patient. Korean journal of anesthesiology. 2020;31(20116):20116-.

34. Moro F, Buonsenso D, Moruzzi MC, Inchingolo R, Smargiassi A, Demi L, et al. How to perform lung ultrasound in pregnant women with suspected COVID-19 infection. Ultrasound in obstetrics \& gynecology : the official journal of the International Society of Ultrasound in Obstetrics and Gynecology. 2020;24(10):22028-.

35. Chen DJ, Yang HX, Cao Y, Cheng WW, Duan T, Fan CF, et al. Expert consensus for managing pregnant women and neonates born to mothers with suspected or confirmed novel coronavirus (COVID-19) infection. International Journal of Gynecology \& Obstetrics.

36. Rasmussen SA, Smulian JC, Lednicky JA, Wen TS, Jamieson DJ. Coronavirus Disease 2019 (COVID19) and Pregnancy: What obstetricians need to know. American journal of obstetrics and gynecology. 2020;24(20):30196-7.

37. Kalafat E, Yaprak E, Cinar G, Varli B, Ozisik S, Uzun C, et al. Lung ultrasound and computed tomographic findings in pregnant woman with COVID-19. Ultrasound in obstetrics \& gynecology : the official journal of the International Society of Ultrasound in Obstetrics and Gynecology. 2020;6(10):22034-.

FIGURE LEGEND

\begin{tabular}{ll}
\hline Figure Number & Description \\
\hline 1 & PRISMA Flowchart of shortlisted studies \\
2 & Procedures to follow when a suspected case arrives at the COVID designated clinic \\
\hline
\end{tabular}

\section{TABLE LEGEND}

\begin{tabular}{ll}
\hline Table Number & Description \\
\hline 1 & Characteristics of Included Studies \\
2 & Patient Demographics of Included Studies \\
3 & Identifying other risk factors in COVID-19 Pregnant Mothers \\
4 & Strategies To Deal With Suspected and Confirmed Cases of COVID-19 \\
\hline
\end{tabular}

$\overline{\text { Figure } 1}$ 


\begin{tabular}{|c|c|c|c|c|c|}
\hline $\begin{array}{l}\text { Table 1: } \\
\text { Characteris- } \\
\text { tics of } \\
\text { Included } \\
\text { Studies } \\
\end{array}$ & $\begin{array}{l}\text { Table 1: } \\
\text { Characteris- } \\
\text { tics of } \\
\text { Included } \\
\text { Studies }\end{array}$ & $\begin{array}{l}\text { Table 1: } \\
\text { Characteris- } \\
\text { tics of } \\
\text { Included } \\
\text { Studies }\end{array}$ & $\begin{array}{l}\text { Table 1: } \\
\text { Characteris- } \\
\text { tics of } \\
\text { Included } \\
\text { Studies }\end{array}$ & $\begin{array}{l}\text { Table 1: } \\
\text { Characteris- } \\
\text { tics of } \\
\text { Included } \\
\text { Studies }\end{array}$ & $\begin{array}{l}\text { Table 1: } \\
\text { Characteris- } \\
\text { tics of } \\
\text { Included } \\
\text { Studies }\end{array}$ \\
\hline $\begin{array}{l}\text { Author } \\
\text { Names }\end{array}$ & Study Type & $\begin{array}{l}\text { 1) Paper } \\
\text { Published 2) } \\
\text { Paper in } \\
\text { Press }\end{array}$ & $\begin{array}{l}\text { Risk Bias } \\
\text { Assessment } \\
\text { (New-Castle } \\
\text { Ottawa } \\
\text { Score) for } \\
\text { Case- } \\
\text { Control and } \\
\text { Cohort } \\
\text { Studies }\end{array}$ & $\begin{array}{l}\text { Methodological } \\
\text { Quality of } \\
\text { Case } \\
\text { Reports and } \\
\text { Case Series* }\end{array}$ & $\begin{array}{l}\text { AMSTAR } \\
\text { assessment } \\
\text { of systematic } \\
\text { reviews }\end{array}$ \\
\hline Chen D et al & $\begin{array}{l}\text { Perspective } \\
\text { Report }\end{array}$ & 2 & $\mathrm{~N} / \mathrm{A}$ & $\mathrm{N} / \mathrm{A}$ & \\
\hline Poon LC et al & $\begin{array}{l}\text { Guideline } \\
\text { Document }\end{array}$ & 2 & $\mathrm{~N} / \mathrm{A}$ & $\mathrm{N} / \mathrm{A}$ & \\
\hline Chen Y et al & Case Series & 2 & & ++++++ & \\
\hline Chen $\mathrm{S}$ et al & $\begin{array}{l}\text { Retrospective } \\
\text { Cohort }\end{array}$ & 2 & $* * * *$ _ $* * *$ & & \\
\hline Poon LC et al & Guidelines & 2 & & & \\
\hline Moro F et al & $\begin{array}{l}\text { Technical } \\
\text { Report }\end{array}$ & 2 & & & \\
\hline Kalafat E et al & Case Report & 2 & & +++++++ & \\
\hline $\begin{array}{l}\text { Zaigham M et } \\
\text { al }\end{array}$ & Review Article & 2 & & & 5 \\
\hline Liu D et al & $\begin{array}{l}\text { Retrospective } \\
\text { Cohort }\end{array}$ & 1 & $* * * * * * *$ & & \\
\hline Shwartz DA et al & $\begin{array}{l}\text { Retrospective } \\
\text { Cohort }\end{array}$ & 2 & $* * * * * * * *$ & & \\
\hline Panah L et al & Review Article & 1 & & & 6 \\
\hline Lee DH et al & Case Report & 2 & & +++++++ & \\
\hline Mullins E et al & Review Article & 2 & & & 3 \\
\hline Li N et al & $\begin{array}{l}\text { Case Control } \\
\text { Study }\end{array}$ & 2 & $* * * * * * *$ & & \\
\hline Wang $S$ et al & Case Report & 1 & & +++++++ & \\
\hline Chen $\mathrm{H}$ et al & $\begin{array}{l}\text { Retrospective } \\
\text { Cohort }\end{array}$ & 1 & $* * * * * * * * *$ & & \\
\hline $\mathrm{Yu} \mathrm{N}$ et al & $\begin{array}{l}\text { Retrospective } \\
\text { Cohort }\end{array}$ & 1 & $* * * * * * *$ & & \\
\hline Fan C et al & Case Series & 2 & & +++++++ & \\
\hline $\begin{array}{l}\text { Rasmussen et } \\
\text { al }\end{array}$ & $\begin{array}{l}\text { Perspective } \\
\text { Report }\end{array}$ & 1 & $\mathrm{~N} / \mathrm{A}$ & $\mathrm{N} / \mathrm{A}$ & \\
\hline $\begin{array}{l}\text { Dashraath P } \\
\text { et al }\end{array}$ & $\begin{array}{l}\text { Perspective } \\
\text { Report }\end{array}$ & 2 & $\mathrm{~N} / \mathrm{A}$ & $\mathrm{N} / \mathrm{A}$ & \\
\hline Wang SS et al & $\begin{array}{l}\text { Perspective } \\
\text { Report }\end{array}$ & 1 & $\mathrm{~N} / \mathrm{A}$ & $\mathrm{N} / \mathrm{A}$ & \\
\hline Liu $\mathrm{H}$ et al & $\begin{array}{l}\text { Retrospective } \\
\text { Cohort }\end{array}$ & 2 & $* * * * * * *$ & $\mathrm{~N} / \mathrm{A}$ & \\
\hline
\end{tabular}




\begin{tabular}{|c|c|c|c|c|c|c|c|}
\hline $\begin{array}{l}\text { Table 2: } \\
\text { Patient } \\
\text { Demo- } \\
\text { graphics } \\
\text { of } \\
\text { Included } \\
\text { Studies }\end{array}$ & $\begin{array}{l}\text { Table 2: } \\
\text { Patient } \\
\text { Demo- } \\
\text { graphics } \\
\text { of } \\
\text { Included } \\
\text { Studies }\end{array}$ & $\begin{array}{l}\text { Table 2: } \\
\text { Patient } \\
\text { Demo- } \\
\text { graphics } \\
\text { of } \\
\text { Included } \\
\text { Studies }\end{array}$ & $\begin{array}{l}\text { Table 2: } \\
\text { Patient } \\
\text { Demo- } \\
\text { graphics } \\
\text { of } \\
\text { Included } \\
\text { Studies }\end{array}$ & $\begin{array}{l}\text { Table 2: } \\
\text { Patient } \\
\text { Demo- } \\
\text { graphics } \\
\text { of } \\
\text { Included } \\
\text { Studies }\end{array}$ & $\begin{array}{l}\text { Table 2: } \\
\text { Patient } \\
\text { Demo- } \\
\text { graphics } \\
\text { of } \\
\text { Included } \\
\text { Studies }\end{array}$ & $\begin{array}{l}\text { Table 2: } \\
\text { Patient } \\
\text { Demo- } \\
\text { graphics } \\
\text { of } \\
\text { Included } \\
\text { Studies }\end{array}$ & $\begin{array}{l}\text { Table 2: } \\
\text { Patient } \\
\text { Demo- } \\
\text { graphics } \\
\text { of } \\
\text { Included } \\
\text { Studies }\end{array}$ \\
\hline $\begin{array}{l}\text { Author } \\
\text { Names }\end{array}$ & $\begin{array}{l}\text { Sample } \\
\text { Size (preg- } \\
\text { nancies) }\end{array}$ & $\begin{array}{l}\text { Trimester } \\
\text { of } \\
\text { Pregnancy }\end{array}$ & $\begin{array}{l}\text { Geographical } \\
\text { Location* }\end{array}$ & $\begin{array}{l}\text { Fever at } \\
\text { presenta- } \\
\text { tion }\end{array}$ & Cough & $\begin{array}{l}\text { Respiratory } \\
\text { Distress }\end{array}$ & $\begin{array}{l}\text { Contact } \\
\text { History }\end{array}$ \\
\hline $\begin{array}{l}\text { Chen D et } \\
\text { al }\end{array}$ & - & - & China & - & - & - & - \\
\hline $\begin{array}{l}\text { Poon LC } \\
\text { et al }\end{array}$ & 56 & $\begin{array}{l}2^{\text {nd }} \text { and } \\
3^{\text {rd }}\end{array}$ & China & $\begin{array}{l}\text { In } \\
\text { majority } \\
\text { of patients }\end{array}$ & $\begin{array}{l}\text { In } \\
\text { majority } \\
\text { of patients }\end{array}$ & - & Yes \\
\hline $\begin{array}{l}\text { Chen Y et } \\
\text { al }\end{array}$ & 3 & $\begin{array}{l}2\left(1^{\text {st }}\right), 1 \\
\left(3^{\text {rd }}\right)\end{array}$ & China & - & - & - & Yes \\
\hline $\begin{array}{l}\text { Chen S et } \\
\text { al }\end{array}$ & 5 & $3^{\text {rd }}$ & China & $\begin{array}{l}\text { In } \\
\text { majority } \\
\text { of patients }\end{array}$ & $\begin{array}{l}\text { In } \\
\text { majority } \\
\text { of patients }\end{array}$ & Present & - \\
\hline $\begin{array}{l}\text { Poon LC } \\
\text { et al }\end{array}$ & - & - & $\begin{array}{l}\text { Hong } \\
\text { Kong }\end{array}$ & Yes & $\begin{array}{l}\text { In } \\
\text { majority } \\
\text { of patients }\end{array}$ & Present & Yes \\
\hline $\begin{array}{l}\text { Moro F et } \\
\text { al }\end{array}$ & - & - & Italy & - & - & - & - \\
\hline $\begin{array}{l}\text { Kalafat E } \\
\text { et al }\end{array}$ & 1 & $3^{\mathrm{rd}}$ & Turkey & No & No & Present & - \\
\hline $\begin{array}{l}\text { Zaigham M } \\
\text { et al }\end{array}$ & 22 & $\begin{array}{l}20 \%\left(1^{\mathrm{st}}\right) \\
80 \%\left(3^{\mathrm{rd}}\right)\end{array}$ & $\begin{array}{l}\text { China, USA, } \\
\text { Korea, } \\
\text { Honduras }\end{array}$ & $\begin{array}{l}68 \% \\
\text { reported } \\
\text { fever }\end{array}$ & $\begin{array}{l}34 \% \\
\text { reported } \\
\text { cough }\end{array}$ & $\begin{array}{l}12 \% \\
\text { reported } \\
\text { distress }\end{array}$ & - \\
\hline $\begin{array}{l}\text { Liu D et } \\
\text { al }\end{array}$ & 15 & $1^{\mathrm{st}}-3^{\mathrm{rd}}$ & - & $\begin{array}{l}87 \% \\
\text { reported } \\
\text { fever }\end{array}$ & $\begin{array}{l}60 \% \\
\text { reported } \\
\text { cough }\end{array}$ & $\begin{array}{l}7 \% \\
\text { reported } \\
\text { distress }\end{array}$ & $\begin{array}{l}13 \% \\
\text { reported } \\
\text { contact }\end{array}$ \\
\hline $\begin{array}{l}\text { Shwartz } \\
\text { DA et al }\end{array}$ & 38 & $3^{\mathrm{rd}}$ & China & $\begin{array}{l}78 \% \\
\text { reported } \\
\text { fever }\end{array}$ & $\begin{array}{l}44 \% \\
\text { reported } \\
\text { cough }\end{array}$ & $\begin{array}{l}11 \% \\
\text { reported } \\
\text { distress }\end{array}$ & None \\
\hline $\begin{array}{l}\text { Panah L } \\
\text { et al }\end{array}$ & 37 & - & - & $\begin{array}{l}\text { In } \\
\text { majority } \\
\text { of patients }\end{array}$ & $\begin{array}{l}\text { In } \\
\text { majority } \\
\text { of patients }\end{array}$ & - & - \\
\hline $\begin{array}{l}\text { Lee DH et } \\
\text { al }\end{array}$ & 1 & $3^{\mathrm{rd}}$ & Korea & Yes & Yes & - & Yes \\
\hline $\begin{array}{l}\text { Mullins E } \\
\text { et al }\end{array}$ & 32 & $3^{\mathrm{rd}}$ & - & - & - & $\begin{array}{l}6 \% \\
\text { reported } \\
\text { distress }\end{array}$ & - \\
\hline Li N et al & 121 & - & China & $\begin{array}{l}\text { Very few } \\
\text { had fever }\end{array}$ & $\begin{array}{l}\text { Very few } \\
\text { had cough }\end{array}$ & - & - \\
\hline $\begin{array}{l}\text { Wang } S \text { et } \\
\text { al }\end{array}$ & 1 & $3^{\text {rd }}$ & China & Yes & No & - & No \\
\hline $\begin{array}{l}\text { Chen } \mathrm{H} \text { et } \\
\text { al }\end{array}$ & 3 & $3^{\mathrm{rd}}$ & China & $\begin{array}{l}78 \% \\
\text { reported } \\
\text { fever }\end{array}$ & $\begin{array}{l}44 \% \\
\text { reported } \\
\text { cough }\end{array}$ & - & No \\
\hline
\end{tabular}




\begin{tabular}{|c|c|c|c|c|c|c|c|}
\hline $\begin{array}{l}\text { Table 2: } \\
\text { Patient } \\
\text { Demo- } \\
\text { graphics } \\
\text { of } \\
\text { Included } \\
\text { Studies }\end{array}$ & $\begin{array}{l}\text { Table 2: } \\
\text { Patient } \\
\text { Demo- } \\
\text { graphics } \\
\text { of } \\
\text { Included } \\
\text { Studies }\end{array}$ & $\begin{array}{l}\text { Table 2: } \\
\text { Patient } \\
\text { Demo- } \\
\text { graphics } \\
\text { of } \\
\text { Included } \\
\text { Studies }\end{array}$ & $\begin{array}{l}\text { Table 2: } \\
\text { Patient } \\
\text { Demo- } \\
\text { graphics } \\
\text { of } \\
\text { Included } \\
\text { Studies }\end{array}$ & $\begin{array}{l}\text { Table 2: } \\
\text { Patient } \\
\text { Demo- } \\
\text { graphics } \\
\text { of } \\
\text { Included } \\
\text { Studies }\end{array}$ & $\begin{array}{l}\text { Table 2: } \\
\text { Patient } \\
\text { Demo- } \\
\text { graphics } \\
\text { of } \\
\text { Included } \\
\text { Studies }\end{array}$ & $\begin{array}{l}\text { Table 2: } \\
\text { Patient } \\
\text { Demo- } \\
\text { graphics } \\
\text { of } \\
\text { Included } \\
\text { Studies }\end{array}$ & $\begin{array}{l}\text { Table 2: } \\
\text { Patient } \\
\text { Demo- } \\
\text { graphics } \\
\text { of } \\
\text { Included } \\
\text { Studies }\end{array}$ \\
\hline $\mathrm{Yu} \mathrm{N}$ et al & 7 & $3^{\mathrm{rd}}$ & China & $\begin{array}{l}86 \% \\
\text { reported } \\
\text { fever }\end{array}$ & $\begin{array}{l}14 \% \\
\text { reported } \\
\text { cough }\end{array}$ & - & No \\
\hline $\begin{array}{l}\text { Fan C et } \\
\text { al }\end{array}$ & 2 & $3^{\mathrm{rd}}$ & China & $\begin{array}{l}50 \% \\
\text { reported } \\
\text { fever }\end{array}$ & $\begin{array}{l}50 \% \\
\text { reported } \\
\text { cough }\end{array}$ & - & No \\
\hline $\begin{array}{l}\text { Rasmussen } \\
\text { et al }\end{array}$ & - & - & - & - & - & - & - \\
\hline $\begin{array}{l}\text { Dashraath } \\
\mathrm{P} \text { et al }\end{array}$ & - & - & - & - & - & - & - \\
\hline $\begin{array}{l}\text { Wang SS } \\
\text { et al }\end{array}$ & - & - & China & Yes & - & - & - \\
\hline $\begin{array}{l}\text { Liu H et } \\
\text { al }\end{array}$ & 59 & - & China & $\begin{array}{l}44 \% \\
\text { reported } \\
\text { fever }\end{array}$ & - & - & - \\
\hline
\end{tabular}




\begin{tabular}{|c|c|c|c|c|c|c|c|}
\hline $\begin{array}{l}\text { Table 2: } \\
\text { Patient } \\
\text { Demo- } \\
\text { graphics } \\
\text { of } \\
\text { Included } \\
\text { Studies }\end{array}$ & $\begin{array}{l}\text { Table 2: } \\
\text { Patient } \\
\text { Demo- } \\
\text { graphics } \\
\text { of } \\
\text { Included } \\
\text { Studies }\end{array}$ & $\begin{array}{l}\text { Table 2: } \\
\text { Patient } \\
\text { Demo- } \\
\text { graphics } \\
\text { of } \\
\text { Included } \\
\text { Studies }\end{array}$ & $\begin{array}{l}\text { Table 2: } \\
\text { Patient } \\
\text { Demo- } \\
\text { graphics } \\
\text { of } \\
\text { Included } \\
\text { Studies }\end{array}$ & $\begin{array}{l}\text { Table 2: } \\
\text { Patient } \\
\text { Demo- } \\
\text { graphics } \\
\text { of } \\
\text { Included } \\
\text { Studies }\end{array}$ & $\begin{array}{l}\text { Table 2: } \\
\text { Patient } \\
\text { Demo- } \\
\text { graphics } \\
\text { of } \\
\text { Included } \\
\text { Studies }\end{array}$ & $\begin{array}{l}\text { Table 2: } \\
\text { Patient } \\
\text { Demo- } \\
\text { graphics } \\
\text { of } \\
\text { Included } \\
\text { Studies }\end{array}$ & $\begin{array}{l}\text { Table 2: } \\
\text { Patient } \\
\text { Demo- } \\
\text { graphics } \\
\text { of } \\
\text { Included } \\
\text { Studies }\end{array}$ \\
\hline$(-)$ & $(-)$ & $(-)$ & $(-)$ & $(-)$ & $(-)$ & $(-)$ & $(-)$ \\
\hline $\begin{array}{l}\text { indicates a } \\
\text { missing }\end{array}$ & $\begin{array}{l}\text { indicates a } \\
\text { missing }\end{array}$ & $\begin{array}{l}\text { indicates a } \\
\text { missing }\end{array}$ & $\begin{array}{l}\text { indicates a } \\
\text { missing }\end{array}$ & $\begin{array}{l}\text { indicates a } \\
\text { missing }\end{array}$ & $\begin{array}{l}\text { indicates a } \\
\text { missing }\end{array}$ & $\begin{array}{l}\text { indicates a } \\
\text { missing }\end{array}$ & $\begin{array}{l}\text { indicates a } \\
\text { missing }\end{array}$ \\
\hline $\begin{array}{l}\text { informa- } \\
\text { tion in the }\end{array}$ & $\begin{array}{l}\text { informa- } \\
\text { tion in the }\end{array}$ & $\begin{array}{l}\text { informa- } \\
\text { tion in the }\end{array}$ & $\begin{array}{l}\text { informa- } \\
\text { tion in the }\end{array}$ & $\begin{array}{l}\text { informa- } \\
\text { tion in the }\end{array}$ & $\begin{array}{l}\text { informa- } \\
\text { tion in the }\end{array}$ & $\begin{array}{l}\text { informa- } \\
\text { tion in the }\end{array}$ & $\begin{array}{l}\text { informa- } \\
\text { tion in the }\end{array}$ \\
\hline $\begin{array}{l}\text { manuscript } \\
(*) \text { in }\end{array}$ & $\begin{array}{l}\text { manuscript } \\
(*) \text { in }\end{array}$ & $\begin{array}{l}\text { manuscript } \\
(*) \text { in }\end{array}$ & $\begin{array}{l}\text { manuscript } \\
(*) \text { in }\end{array}$ & $\begin{array}{l}\text { manuscript } \\
(*) \text { in }\end{array}$ & $\begin{array}{l}\text { manuscript } \\
(*) \text { in }\end{array}$ & $\begin{array}{l}\text { manuscript } \\
(*) \text { in }\end{array}$ & $\begin{array}{l}\text { manuscript } \\
(*) \text { in }\end{array}$ \\
\hline places & places & places & places & places & places & places & places \\
\hline $\begin{array}{l}\text { where geo- } \\
\text { graphical }\end{array}$ & $\begin{array}{l}\text { where geo- } \\
\text { graphical }\end{array}$ & $\begin{array}{l}\text { where geo- } \\
\text { graphical }\end{array}$ & $\begin{array}{l}\text { where geo- } \\
\text { graphical }\end{array}$ & $\begin{array}{l}\text { where geo- } \\
\text { graphical }\end{array}$ & $\begin{array}{l}\text { where geo- } \\
\text { graphical }\end{array}$ & $\begin{array}{l}\text { where geo- } \\
\text { graphical }\end{array}$ & $\begin{array}{l}\text { where geo- } \\
\text { graphical }\end{array}$ \\
\hline $\begin{array}{l}\text { location of } \\
\text { patients }\end{array}$ & $\begin{array}{l}\text { location of } \\
\text { patients }\end{array}$ & $\begin{array}{l}\text { location of } \\
\text { patients }\end{array}$ & $\begin{array}{l}\text { location of } \\
\text { patients }\end{array}$ & $\begin{array}{l}\text { location of } \\
\text { patients }\end{array}$ & $\begin{array}{l}\text { location of } \\
\text { patients }\end{array}$ & $\begin{array}{l}\text { location of } \\
\text { patients }\end{array}$ & $\begin{array}{l}\text { location of } \\
\text { patients }\end{array}$ \\
\hline haven't & haven't & haven't & haven't & haven't & haven't & haven't & haven't \\
\hline been & been & been & been & been & been & been & been \\
\hline explicitly & explicitly & explicitly & explicitly & explicitly & explicitly & explicitly & explicitly \\
\hline men- & men- & men- & men- & men- & men- & men- & men- \\
\hline tioned, the & tioned, the & tioned, the & tioned, the & tioned, the & tioned, the & tioned, the & tioned, the \\
\hline publishing & publishing & publishing & publishing & publishing & publishing & publishing & publishing \\
\hline institute's & institute's & institute's & institute's & institute's & institute's & institute's & institute's \\
\hline city is & city is & city is & city is & city is & city is & city is & city is \\
\hline cited () & cited () & cited () & cited () & cited () & cited () & cited () & cited () \\
\hline implies & implies & implies & implies & implies & implies & implies & implies \\
\hline trimesters & trimesters & trimesters & trimesters & trimesters & trimesters & trimesters & trimesters \\
\hline $\begin{array}{l}\text { stated in } \\
\text { the }\end{array}$ & $\begin{array}{l}\text { stated in } \\
\text { the }\end{array}$ & $\begin{array}{l}\text { stated in } \\
\text { the }\end{array}$ & $\begin{array}{l}\text { stated in } \\
\text { the }\end{array}$ & $\begin{array}{l}\text { stated in } \\
\text { the }\end{array}$ & $\begin{array}{l}\text { stated in } \\
\text { the }\end{array}$ & $\begin{array}{l}\text { stated in } \\
\text { the }\end{array}$ & $\begin{array}{l}\text { stated in } \\
\text { the }\end{array}$ \\
\hline $\begin{array}{l}\text { manuscript, } \\
\text { with }\end{array}$ & $\begin{array}{l}\text { manuscript, } \\
\text { with }\end{array}$ & $\begin{array}{l}\text { manuscript, } \\
\text { with }\end{array}$ & $\begin{array}{l}\text { manuscript, } \\
\text { with }\end{array}$ & $\begin{array}{l}\text { manuscript, } \\
\text { with }\end{array}$ & $\begin{array}{l}\text { manuscript, } \\
\text { with }\end{array}$ & $\begin{array}{l}\text { manuscript, } \\
\text { with }\end{array}$ & $\begin{array}{l}\text { manuscript, } \\
\text { with }\end{array}$ \\
\hline multiple & multiple & multiple & multiple & multiple & multiple & multiple & multiple \\
\hline cases, the & cases, the & cases, the & cases, the & cases, the & cases, the & cases, the & cases, the \\
\hline most & most & most & most & most & most & most & most \\
\hline reported & reported & reported & reported & reported & reported & reported & reported \\
\hline trimester & trimester & trimester & trimester & trimester & trimester & trimester & trimester \\
\hline $\begin{array}{l}\text { has been } \\
\text { stated }\end{array}$ & $\begin{array}{l}\text { has been } \\
\text { stated }\end{array}$ & $\begin{array}{l}\text { has been } \\
\text { stated }\end{array}$ & $\begin{array}{l}\text { has been } \\
\text { stated }\end{array}$ & $\begin{array}{l}\text { has been } \\
\text { stated }\end{array}$ & $\begin{array}{l}\text { has been } \\
\text { stated }\end{array}$ & $\begin{array}{l}\text { has been } \\
\text { stated }\end{array}$ & $\begin{array}{l}\text { has been } \\
\text { stated }\end{array}$ \\
\hline
\end{tabular}

Table 3: Identifying other risk factors in COVID-19 Pregnant Mothers Table 3: Identifying other risk fac

\begin{tabular}{ll}
\hline Author Names & Key Findings \\
Wang S et al. & More than 15 patients in the same com \\
Chen H et al. & All 9 patients had confirmed epidemiol \\
Yu N et al. & All the 7 patients reported an epidemio \\
Fan C et al. & One of the patient was a physician who \\
\hline
\end{tabular}


$\overline{\text { Figure 2 }}$

\section{Table 4: Strategies To Deal With Suspected and Confirmed Cases of COVID-19}

Patients who develop respiratory symptoms should practice strict respiratory hygiene including coughing and sneezing on a Pregnant females should be isolated in a negative pressure room, regardless whether they are suspected or confirmed

Healthcare providers should take special care in wearing CDC instructed personal protective equipment including N-95 resp Patient's nasopharyngeal or oropharyngeal swabs should be collected and sent to institutes running the SARS-CoV-2 RT-P Make sure that the patient has limited access to relatives and irrelevant staff in the isolation room

Close monitoring of mother's vital signs and diagnostic testing should be done, since pregnancy itself is a high risk conditio Fetal monitoring should be carried out regularly to ensure the wellbeing of the fetus. It's suggested to regularly to check fet In case the mother is in respiratory distress, consider the use of early oxygen therapy with the goal of maintaining $\mathrm{O}_{2}$ satur Use intravenous fluids conservatively unless cardiovascular instability is present

Screen for any other respiratory infection: viral and bacterial

Consider empiric antimicrobial therapy (because of risk for superimposed bacterial infections).

Judicious use of corticosteroids should be done to promote fetal maturity in the setting of an anticipated preterm delivery If septic shock is suspected, institute prompt, targeted management.

Delivery and pregnancy termination decisions should be based on gestational age, maternal condition, and fetal stability, ar 